\title{
Cost Analysis of Various Brands of Antibiotics and Corticosteroids in Dermatology Department
}

\author{
Shareen Simran', Srinidhi Bantwal Chandrashekar', Ansa Anil', Juno Jerold Joel1*, Banavasi Shanmukha Girisha² \\ 'Department of Pharmacy Practice, NGSM Institute of Pharmaceutical Sciences, NITTE (Deemed to be University), Paneer, Deralakatte, Mangaluru, Karnataka, INDIA. \\ ${ }^{2}$ Department of Dermatology, Justice K S Hegde Charitable Hospital, NITTE (Deemed to be University), Paneer, Deralakatte, Mangaluru, Karnataka, INDIA.
}

\begin{abstract}
Background: Skin diseases are referred to the disorders that occur mainly on the superficial layers of the skin. Antibiotics and corticosteroids are commonly used drug classes in the management of skin disorders. Since, the variation in price of antibiotics and corticosteroids used in dermatological departments vary widely, this study was performed to give an insight on the difference of the cost of various brands of antibiotics and corticosteroids available in India. Methods: The 6-month prospective study conducted from September 2018 to March 2019 assessed the cost variability between different brands of antibiotics and corticosteroids commonly prescribed. The cost of various brands of drugs was collected from the Current Index of Medical Specialties (CIMS) and medguideindia.com. Results: It was seen that tablet prednisolone showed the maximum percentage price variation $(4408.67 \%)$ followed by tablet azithromycin that varied by $1607.23 \%$. Conclusion: As the drugs prescribed by brand names are higher than the drugs prescribed in their generic names, the cost effectiveness
\end{abstract}

will not be achieved. This suggests that prescribing drugs in generic name will also have an option for the dispensing pharmacist to provide the suitable drug to the patient.

Key words: Antibiotics, Corticosteroids, Price variation, Dermatology, Cost analysis, Skin diseases.

Correspondence

Dr. Juno J Joel,

Assistant Professor, Department of Pharmacy Practice, NGSM Institute of Pharmaceutical Sciences, NITTE (Deemed to be University), Paneer, Deralakatte, Mangaluru, Karnataka-575018, INDIA.

Phone: +919480470727

Email: junojoel@nitte.edu.in

DOI: 10.5530/jyp.2020.12.36

\section{INTRODUCTION}

Skin diseases are referred to the disorders that occur generally on the superficial layer of the skin. ${ }^{1}$ Antibiotics and corticosteroids are the mainstay in the management of skin disorders and are available in various formulations. Antibiotic is defined as "a chemical substance produced by a micro-organism that kills or inhibits the growth of another micro-organism". Antibiotics are selected according to the target of the organism, location of the application and based on the properties which are unique to other class of antibiotics. ${ }^{2}$ Corticosteroids due to its strong immunosuppressive and anti-inflammatory actions play an important role in dermatological conditions. ${ }^{3}$ The main goal of therapy is to treat with least possible drugs with safe and effectiveness, so as to acquire finest achievable outcome in a short duration at low price. ${ }^{4}$

Health care system across the globe struggle with the increasing drug prices, although a part of it is legitimate and unavoidable. Some explainable factors could be the availability of the novel drug, or the changes in demographics of the patient population. ${ }^{5}$ Several studies have mentioned that drug prices influence therapeutic compliances. In health care system, the cost of prescription can have an impact on Users, Suppliers and most significantly Payers. ${ }^{6}$

Cost analysis on various brands of antibiotics and corticosteroids available in the market provides information on the variation of costs between the brands. Along with the benefits of providing the physician with a broader and cost effective range of medications, cost analysis studies can also in indirect ways, increase ones adherence to his medications resulting in better clinical outcome. Hence, the study was to carry out the cost analysis on various brands of antibiotics and corticosteroids available in the market.

\section{MATERIALS AND METHODS}

A prospective observational study has been carried out in Dermatology out-patient department of a multi-specialty teaching hospital at Mangaluru for a span of six months. The price of particular drug available in different strength and dosage form, which are manufactured under different brands, were compared. Drugs that were available under a single brand were excluded and the percentage price variations of similar drugs were calculated using the formula:

$$
\text { Percentage cost variation }=\frac{\text { Maximum cost }- \text { Minimum cost }}{\text { Minimum cost }} \times 100
$$

The cost of various brands of drugs was collected from the Current Index of Medical Specialties (CIMS) and medguideindia.com. Institutional Ethical Committee ethically approved the present study.

\section{RESULTS}

In this price variation study, 36 drugs, which are available in 212 different formulation, were analysed.

\section{Price variation in Corticosteroids (Single drug therapy and Combination therapy)}

Table 1 depicts that among corticosteroids that are prescribed as single drug therapy, cost variation of Prednisolone $(5 \mathrm{mg}$ ) shows maximum variation in price of $4408.67 \%$ followed by Mometasone $0.1 \%$ of $501.42 \%$, whereas Methylprednisolone 8mg showed minimum Percentage price variation of $3.87 \%$. Among the combination therapy, Beclomethasone + Clotrimazole (20gm) shows maximum price variation of $918.18 \%$. 
Table 1: Price variation in Corticosteroids (Single drug therapy and Combination therapy).

\begin{tabular}{|c|c|c|c|c|c|}
\hline Drugs & Dose & $\begin{array}{c}\text { Manufacturing } \\
\text { Companies }\end{array}$ & $\begin{array}{l}\text { Maximum cost } \\
\text { (Rupees) }\end{array}$ & $\begin{array}{l}\text { Minimum cost } \\
\text { (Rupees) }\end{array}$ & $\begin{array}{l}\text { Percentage price } \\
\text { variation (\%) }\end{array}$ \\
\hline Fluticasone Propionate Cream0.05\%w/w & $10 \mathrm{gm}$ & 5 & 133.4 & 85.00 & 56.94 \\
\hline $\begin{array}{c}\text { Clobetasol cream } \\
0.05 \% \mathrm{w} / \mathrm{w}\end{array}$ & $30 \mathrm{gm}$ & 6 & 143.00 & 65.00 & 120 \\
\hline $\begin{array}{l}\text { T. Betamethasone } \\
20 \text { tablets }\end{array}$ & $1 \mathrm{mg}$ & 2 & 16.05 & 3.64 & 340.93 \\
\hline $\begin{array}{l}\text { T.Betamethasone } \\
10 \text { tablets }\end{array}$ & $1 \mathrm{mg}$ & 3 & 6.8 & 4.98 & 36.54 \\
\hline \multirow{3}{*}{ Halobetasol lotion } & $30 \mathrm{ml}$ & 2 & 222 & 199 & 11.55 \\
\hline & $50 \mathrm{ml}$ & 1 & 248 & - & - \\
\hline & $15 \mathrm{ml}$ & 1 & 90 & - & - \\
\hline Mometasone $0.1 \%$ & $15 \mathrm{gm}$ & 5 & 210.5 & 35.00 & 501.42 \\
\hline Triamcinolone & $40 \mathrm{mg}$ & 6 & 116.5 & 49.0 & 137.75 \\
\hline \multirow{3}{*}{ T. Methylprednisolone } & $16 \mathrm{mg}$ & 5 & 93.73 & 90.22 & 3.89 \\
\hline & $8 \mathrm{mg}$ & 5 & 53.63 & 51.63 & 3.87 \\
\hline & $4 \mathrm{mg}$ & 5 & 42.5 & 40.0 & 6.25 \\
\hline \multirow{2}{*}{ Desonide Cream } & $10 \mathrm{mg}$ & 4 & 168.5 & 67.0 & 151.49 \\
\hline & $15 \mathrm{mg}$ & 2 & 120.0 & 110.0 & 9.090 \\
\hline Desonide lotion & $30 \mathrm{ml}$ & 2 & 184.4 & 128.0 & 44.06 \\
\hline T. Prednisolone & $5 \mathrm{mg}$ & 7 & 156.0 & 3.46 & 4408.67 \\
\hline Hydrocortisone & $100 \mathrm{mg}$ & 5 & 41.05 & 20.81 & 97.26 \\
\hline \multirow{2}{*}{ Clobetasol + Salicylic acid cream } & $10 \mathrm{gm}$ & 1 & 31.76 & - & - \\
\hline & $20 \mathrm{gm}$ & 3 & 86.00 & 60.00 & 43.3 \\
\hline \multirow{3}{*}{ Clobetasol + Salicylic acid ointment } & $20 \mathrm{gm}$ & 4 & 159.0 & 126.0 & 26.19 \\
\hline & $30 \mathrm{gm}$ & 3 & 225.0 & 95.0 & 136.84 \\
\hline & $20 \mathrm{ml}$ & 1 & 140.00 & - & - \\
\hline \multirow[t]{2}{*}{ Halobetasol + Salicylic acid lotion } & $30 \mathrm{ml}$ & 1 & 218.00 & - & - \\
\hline & $50 \mathrm{ml}$ & 1 & 301.28 & - & - \\
\hline \multirow{3}{*}{ Clobetasone + Miconazole } & $15 \mathrm{mg}$ & 4 & 83.7 & 32.00 & 161.56 \\
\hline & $10 \mathrm{mg}$ & 1 & 23.5 & - & - \\
\hline & $15 \mathrm{gm}$ & 3 & 69.7 & 35.00 & 99.14 \\
\hline \multirow[t]{2}{*}{ Beclomethasone + Clotrimazole } & $20 \mathrm{gm}$ & 2 & 112.0 & 110.00 & 918.18 \\
\hline & $30 \mathrm{gm}$ & 1 & 127.00 & - & - \\
\hline Mometasone + Clotrimazole & $10 \mathrm{gm}$ & 2 & 178.0 & 116.5 & 52.78 \\
\hline
\end{tabular}

\section{Price variation in Antibiotics (Single drug therapy and Combination therapy):}

Table 2 shows that in cost variation study of Antibiotics used as single drug therapy, Azithromycin (250mg) shows maximum price variation of $1607.23 \%$ followed by Minocycline ( $45 \mathrm{mg}$ ) of $473.68 \%$ and least price variation was seen in Fusidic acid (5gm) of 2.45\%, whereas in combination therapy, maximum price variation was seen in Clindamycin + Tretinoin (15gm) $380.26 \%$ and least price variation was seen in combination of Betamethasone + Fusidic acid (15gm) 5.12\%.

\section{DISCUSSION}

Antibiotics and corticosteroids are one of the commonly used drug classes in the management of the skin disorders. These drugs are available in various formulations. Among various drugs being prescribed, very few drugs were prescribed in their generic name. This study discloses that the cost of most of the brands of antibiotics and corticosteroids have percentage price variation above $100 \%$, which is not satisfactory state for most of the patients. Out of 36 drugs which are commonly prescribed showed extensive percentage price variation leading to monetary hardship on the consumer. ${ }^{6}$ Unlike developed countries, in India the medical costs for most of the patients are not covered by insurance scheme. Hence, the medical bills will be paid by them alone.?

In this situation, it is advisable that the enormous difference of price between various brands should be managed. In another way, if the data regarding the prices of drug were easily accessible, then the physician will have an option to choose the required brand to reduce the patient's drug expense. Hence, to some extent, it will reduce the commercial hardships on the patients. ${ }^{8}$

A huge number of branded formulations are available in Indian market for almost all the drug molecules, with simultaneous cost differences between the different brands of same formulations. This by itself could create some sort of confusion among the innocent customers leading to be misguided by biased dealers. ${ }^{9}$ This variation of pricing within the 
Table 2: Price variation in Antibiotics (Single drug therapy and Combination therapy).

\begin{tabular}{|c|c|c|c|c|c|}
\hline Drugs & Dose & $\begin{array}{l}\text { Manufacturing } \\
\text { companies }\end{array}$ & $\begin{array}{l}\text { Maximum cost } \\
\text { (Rupees) }\end{array}$ & $\begin{array}{l}\text { Minimum cost } \\
\text { (Rupees) }\end{array}$ & $\begin{array}{l}\text { Percentage price } \\
\text { variation (\%) }\end{array}$ \\
\hline Cap. Cefalexin & $500 \mathrm{mg}$ & 5 & 162.00 & 52.5 & 208.57 \\
\hline \multirow[t]{2}{*}{ Cefixime } & $100 \mathrm{mg}$ & 6 & 95.0 & 54.05 & 75.76 \\
\hline & $5 \mathrm{gm}$ & 3 & 47.95 & 46.8 & 2.45 \\
\hline \multirow[t]{2}{*}{ Fusidicacid cream $2 \% \mathrm{w} / \mathrm{w}$} & $10 \mathrm{gm}$ & 7 & 165.00 & 64.00 & 157.81 \\
\hline & $15 \mathrm{gm}$ & 1 & 143.75 & - & - \\
\hline T. Doxycycline & $100 \mathrm{mg}$ & 6 & 59.92 & 15.00 & 299.46 \\
\hline Minocycline & $45 \mathrm{mg}$ & 5 & 1090.00 & 190.00 & 473.68 \\
\hline Cefadroxil & $500 \mathrm{mg}$ & 6 & 42.45 & 36.52 & 16.23 \\
\hline Nadoxin cream & $10 \mathrm{gm}$ & 6 & 111.55 & 39.7 & 180.98 \\
\hline Erythromycin & $60 \mathrm{ml}$ & 2 & 41.3 & 24.67 & 67.40 \\
\hline Azithromycin & $250 \mathrm{mg}$ & 7 & 110.97 & 6.5 & 1607.23 \\
\hline \multirow{2}{*}{ Benzoyl peroxide } & $20 \mathrm{mg}$ & 4 & 78.5 & 49.37 & 59.00 \\
\hline & $30 \mathrm{mg}$ & 2 & 118.1 & 110.02 & 7.34 \\
\hline \multirow{2}{*}{ Benzoyl peroxide + Clindamycin } & $15 \mathrm{gm}$ & 4 & 339.0 & 198.0 & 71.21 \\
\hline & $25 \mathrm{gm}$ & 1 & 240.0 & - & - \\
\hline \multirow{2}{*}{ Cap. Doxycycline + Lactobacillus } & 10cap & 6 & 84.1 & 69.5 & 21.007 \\
\hline & 8cap & 1 & 65.5 & - & - \\
\hline \multirow[t]{2}{*}{ Amoxicillin+ Clavulanic acid 10tabs } & $625 \mathrm{mg}$ & 5 & 182.3 & 144.75 & 25.94 \\
\hline & $10 \mathrm{gm}$ & 1 & 60.0 & - & - \\
\hline \multirow[t]{2}{*}{ Clindamycin + Tretinoin } & $15 \mathrm{gm}$ & 3 & 60.8 & 292.26 & 380.26 \\
\hline & $20 \mathrm{gm}$ & 1 & 110.0 & - & - \\
\hline Mometasone $0.1 \%$ + Fusidic acid $2 \%$ & $10 \mathrm{gm}$ & 5 & 245.00 & 165.00 & 48.48 \\
\hline \multirow{2}{*}{ Hydrocortisone + Fusidic acid } & $5 \mathrm{gm}$ & 2 & 132.95 & 59.95 & 121.76 \\
\hline & $15 \mathrm{gm}$ & 1 & 170 & - & - \\
\hline \multirow{2}{*}{ Betamethasone + Fusidic acid } & $10 \mathrm{gm}$ & 2 & 77.00 & 42.9 & 79.48 \\
\hline & $15 \mathrm{gm}$ & 2 & 58.45 & 55.6 & 5.12 \\
\hline \multirow{3}{*}{ Clobetasol + Fusidic acid } & $10 \mathrm{gm}$ & 3 & 162.0 & \multirow{3}{*}{$\begin{array}{c}107.25 \\
160.0\end{array}$} & 51.04 \\
\hline & $15 \mathrm{gm}$ & 2 & 180.0 & & 12.5 \\
\hline & $20 \mathrm{gm}$ & 1 & 276.0 & & - \\
\hline
\end{tabular}

brands can be condensed by prescribing the drugs according to their generic names. ${ }^{10}$ Cost analysis was done to study the variation in the prices between different brands of the same generic corticosteroid medication (monotherapy) and it was found that highest percentage variation was seen between brands of tablet Prednisolone (4408.67\%). In case of single drug therapy of antibiotics it was found that Azithromycin (250mg) showed a maximum price variation of $1607.23 \%$.

Among the drugs prescribed in combination, it was observed that Beclomethasone + Clotrimazole showed maximum price variation (918.18\%) followed by Clindamycin + Tretinoin (380.26\%) and the least price variation was seen in the combination of Betamethasone + Fusidic acid $(5.12 \%)$. Thus, this study highlights the huge price variation among the single drug therapy of antibiotics and corticosteroids as well as the combination of antibiotics and corticosteroids. Very less similar studies are conducted in Indian scenario, which compares the prices of different brands of drugs.

\section{CONCLUSION}

Cost analysis on various brands of Corticosteroids and Antibiotics available in the market reports that, there is enormous difference in cost variation among the drugs. It is suggested that, if there is a ready reckoner which contains the price details of different drugs which are available in the market, the prescribers will have an option to choose the required brand for their patients, to reduce the overall treatment cost.

\section{ACKNOWLEDGEMENT}

The authors wish to thank NITTE (Deemed to be University) for providing necessary facilities to carry out this study.

\section{CONFLICT OF INTEREST}

The authors declare none.

\section{ABBREVIATIONS}

CIMS: Current Index of Medical Specialties.

\section{REFERENCES}

1. Narwane SP, PatelTC, Shetty YC, Chikhalkar SB. Drug utilization and cost analysis for common skin diseases in dermatology OPD of an Indian tertiary care hospital: A prescription survey. J Pharm Res Int. 2011;10(2):9-18.

2. Drucker CR. Update on topical antibiotics in dermatology. Dermatol Ther. 
2012;25(1):6-11.

3. Bylappa BK, Patil RT, Pillai RT. Drug prescribing pattern of topical corticosteroids in dermatology unit of a tertiary-care hospital. Int J Med Sci Public Health. 2015;4(12):1702.

4. Sweileh WM. Audit of prescribing practices of topical corticosteroids in outpatient dermatology clinics in north Palestine. EMHJ-Eastern Mediterranean Health J. 2006;12(1-2):161-9.

5. Hirsch O, Schulz M, Erhart M, Donner-Banzhoff N. Factors associated with prescribing costs: analysis of a nationwide administrative database. Cost Effectiveness and Resource Allocation. 2018;16(1):5.

6. Karve AV, Chattar KB. Cost analysis study of oral antihypertensive agents available in Indian market. Int J Basic ClinPharmacol. 2014;3(3):479-83.
7. Deepak KR, Geetha A. Cost variation analysis of various brands of anticoagulants, fibrinolytics and antiplatelet drugs currently available in Indian pharmaceutical market. National J Physiol, Pharm and Pharmacol. 2019;9(5):368-72.

8. Frazier LM, Brown JT, Divine GW, Fleming GR, Philips NM, Siegal WC Khayrallah MA. Can physician education lower the cost of prescription drugs?: A prospective, controlled trial. Annals Internal Med. 1991;115(2):116-21.

9. Das SC. A critical study on availability and price variation between different brands: Impact on access to medicines. Indian J Pharm Sci. 2007;69(1):160.

10. Dawadi S, Rao BS, Khan GM. Pattern of antimicrobial prescription and its cost analysis in respiratory tract infection. Kathmandu University J Sci, Eng and Tech. 2005: 1(1):1-9

Article History: Submission Date : 20-03-2020; Revised Date : 19-04-2020; Acceptance Date : 10-06-2020.

Cite this article: Simran S, Srinidhi BC, Anil A, Joel JJ, Girisha BS. Cost Analysis of Various Brands of Antibiotics and Corticosteroids in Dermatology Department. J Young Pharm. 2020;12(2):178-81. 